\title{
Students' Perceptions about using Website to Learn Vocabulary in English for Specific Classroom
}

\author{
Ly Minh Trinh ${ }^{1}$, Son Hoang Le ${ }^{2}$ \\ ${ }^{1}$ Mekong University, Vietnam \\ ${ }^{2}$ University of Economics Ho Chi Minh City, Vietnam
}

\begin{abstract}
:
This study was conducted to investigate students' perceptions about using the website to learn vocabulary in English for Specific classroom. 27 students studying the third year at a university in the Mekong Delta of Vietnam were selected for the study. After ten weeksusing the website to learn and practice vocabulary outside the classroom, the questionnaire was employed to collect the qualitative data. The findings showed that students had positive perceptions about using a website to learn vocabulary. The participating students also indicated that using a website helps students feel less stressed and remember the words better. The study also showed some implications for teachers and students in using ICT as a helpful tool in enhancing students' motivations.
\end{abstract}

Key words: website, ICT, English for Specific, vocabulary.

\section{Introduction}

English is the language for international communication, and is considered as one of the essential languages in the world (Graddol, 2004). Furthermore, with the development of technologies, English is increasingly needed and plays a crucial role in many fields, including medicine, engineering, and education (Ilyosovna, 2020). It is indispensible for EFL students to have a good command to succeed in their academic achievement to meet demand of their country (Nation, 2001). Vocabulary is perceived as an important means for EFL learners because limited vocabulary in a foreign language interferes with successful communication (Alqahtani, 2015; Gu, 2003; Marion, 2008; Nation, 2001; Vu and Michel, 2021). With restricted vocabulary, students are more likely to perform poorly on language acquisition examinations (August et al., 2005).Student can express more things if they have abundant vocabularies.Nowadays, there are the changes in learning and teaching language hasperformed. In English for Specific class, teachers have been trying to provide students with various methods to help students learn specialized English vocabulary such as explanations, translations, pictures, etc. (Hoang, 2017; Ur, 2009). It is still challenges for students to learn unfamiliar words and use them in suitable way. Furthermore, information communication technology (ICT) has been producing more sophisticated tools for language learning over the past decade, which facilitates autonomous learning (Godwin-Jones, 2011; Kuo, 2009). According to Pino (2008) the use of online learning tools gives students the full opportunity to learn and mastery of complex English patterns.

However, only a few studies on using websites to learn ESP vocabulary in Vietnam haveconducted. Therefore, this study presents students' perceptions of using the website to learn vocabulary at a Vietnamese university. This research questions was posed"What are students' perceptions towards learning vocabulary when using website in ESP classroom?"

\section{Literature review}

\subsection{Definition of vocabulary}

There are many concepts of vocabulary mentioned by different researchers. Vocabulary is viewed as understanding of words and "their meanings" (Nash and Snowling, 2006). In addition, Hornby (2006) defined vocabulary as the words people know and use that are a list of words, especially in a book for foreign language. Schmidt (2010) says that vocabulary is a collection of lexemes that includes single words, compound words, and idioms. It is pivotalin English language instruction since students cannot understand others or express themselves without having enough vocabulary.Vocabulary can be described as a collection of words and a specific language used to form sentences. 


\subsection{The important of vocabulary}

The importance of vocabulary in learning English cannot be overstated.According to Wilkins (1972), there is no valuable to produce grammatical sentences if you lack vocabulary, but you can convey your ideas with vocabulary without enough grammar knowledge. Besides, according to Schmitt (2000), he pointed that lexical knowledge is essential for communicative skills and second language learning. Nation (2001) represented that vocabulary knowledge and language use like the complementary relationship: vocabulary knowledge facilitates language use and vice versa. Vocabulary knowledge grows as a result of language use.Rivers (in Nunan, 1991:117) stated that having a robust vocabulary is essential for successful second language use. We will not use the structures and functions we learn to communicate in an understandable way without the vocabulary. Richard and Renandya (2002) emphasized "vocabulary is a core component of language ability, which provides a great foundation for learners' speaking, listening, reading and writing skills" (p.255). In addition, many researchers stated that one of the keys to mastering English is having a large vocabulary (Marion, 2008; Nation, 2001; Nurteteng\&Nopitasari, 2019; Schmitt, Wun-Ching, andGarras, 2011).Vocabulary acquisition is critical for successful second language use and plays a significant role in the formation of complete spoken and written texts (Gu, 2003; Marion, 2008; Nation, 2001).

\subsection{The roles of technology in learning language}

In learning English, the combination of Internet with technological advances allows learners acquire knowledge, improve English language skills (Teeler and Gray, 2000). Technology can generate student-centered atmosphere rather than teacher (Dawson, Cavanaugh, and Ritzhaup, 2008; PourhoseinGilakjani, 2014). They revealed that based on using computer technology, the students are able to be more responsible for their learning and the class becomes livelier.

Due to the development of technology, English teaching methods have changed and provide alternative opportunities to make the classroom more enjoyable and productive (Lock, 2012; Patel, 2013).

Parvin and Salam (2015) showed that students had more chance to expose language in a meaningful context and made their own language. The study indicated that students should be able to engage in social interactions in order to practice real-world skills. This is accomplished by the participation of students in real-life activities.

\subsection{Vocabulary learning and technology}

Learning vocabulary is a complex and difficult process (Ellis, 1994). Alqahtani (2015) revealed that vocabulary refers to the words we use to communicate effectively when speaking (expressive vocabulary) as well as in listening (receptive vocabulary).

In the development of digital era, Internet enables students to gain access to a large amount of authentic material that will make learning English more enjoyable (Dang, 2011).There are several studies brought to light that ICT tools have now removed the time and space constraints found in traditional teaching. Classroom interaction between teacher and student can now be extended beyond the constraints of time and space. The use of ICT tools in the classroom and the process of learning English have been found to have some advantages. Aside from motivating students, ICT can improve learners' interaction, verbalization, and self-esteem, confidence and enrollment in collaborative learning (Altiner, 2011; Dang, 2011;Liu, 2009; Mufliharsi and Candra, 2017; Parvin and Salam, 2015).

According to Liu (2009), technologies are becoming more critical in the classroom and at home, as computerassisted interaction technologies that support the traditional teaching method. Technologies are promptly gaining the attention and interest of teachers and students in EFL classrooms (Kopinska, 2013). In addition, ICT integration drives learner motivation because of multimedia supporting including visual aids, audio, video (Altiner, 2011). Therefore, it can increase engagement of students of different abilities and proficiencies (Khany, and Khosravian, 2013)

\subsection{Related studies}

In a study by Parvin and Salam (2015) about the effectiveness of using technology in EFL classroom in Bangladesh, they indicated that the use of visual aid have great potential and stimulating interactive language class. The classroom environment was more pleasurable. Students were attentive, eager, and curious due to the utilization of electronic content. 
Köse and his colleagues (2016) attempted to investigate the effectiveness of Quizlet on developing vocabulary students at a university in Turkey. There were participated of 43 students. The teaching module lasted seven weeks. During the first three weeks, students learn vocabulary without using the online Quizlet website. Then, students are assigned assignments from an online tool that includes lessons learned from the previous week for the next four weeks. Classroom observations, interviews and students recorded were used to collect the data during the course. The findings showed that students considered the effective online tool in learning vocabulary, synonyms, and pronunciation through repetition.

With the aim to improve non English major students' perspective in learning English, especially ESP syllabus, Mufliharsi and Candra (2017) conducted a study with the participation of 45 students. The authors have used a website to support their students in improving vocabulary. After instruction with the website, the participants answered five questions which referred to students' pleasure, interest, need, achievement, and recommendations. The result of the study revealed that students were satisfied with using the website in learning vocabulary; they felt less pressure to do the exercises on the website. Students found that they can remember more vocabulary than they thought and increase their vocabulary naturally.

Hajebi and his colleagues (2018) conducted a study in Iran to prove the effect of the web-based language learning on the vocabulary of students and student's attitudes about using web-based approach in language class. An experiment group $(n=33)$ used free vocabulary learning websites to learn IELTS vocabulary for 8 weeks and a control group $(n=33)$ only received classroom instruction in each session. The overall results indicated that students' vocabulary knowledge had a significant difference between the experimental group and the control group. Students' vocabulary knowledge is increased with web-based language learning. Students' perceptions have improved with learning that incorporates web instructions. The study also revealed that it is beneficial for curriculum designers in language learning and teaching to generate and augment the motivation to apply online websites for autonomous language learning.

According to Hoang (2018), to explore the effectiveness of the Internet in enhancing business learners' autonomy and improving their learning ability, the author conducted the study with the participants of 200 students and 10 teachers at ThuongMai University, Vietnam. He revealed that students were aware of the importance of using the Internet to promote learner autonomy. Yet, they had used the Internet ineffectively in improving English study and motivation.

Klimova and Polakova (2020) carried out a study to investigate students' perceptions of the use of mobile application in learning new vocabulary in EFL classroom with the participation of 28 students who were studying third year in Hradec Kralove. The finding demonstrated that the students had positive perceptions about using mobile application to learn vocabulary. Using a mobile app made it possible for students to learn vocabulary at any time, and helped them prepare for the final exam. On the other hand, the finding also revealed that the application did not help learners develop communication skills. The findings of the study add to our understanding of students' perceptions of the use of mobile apps for learning.

\section{Methodology}

\subsection{Methodology}

With the aim toexplore students' perceptions about using website to learn vocabulary in ESP classroom, the participant students were instructed to use website "easyword.in" whenlearning language outside the class for 10 weeks. The website was tailored students' needs according to the skills and vocabulary they need to practice. Then the questionnaire involved 13items using a five-point Likert scale which ranged from number 1 to 5.Thefive-point Likert scale ranging from 1- strongly disagree, 2- disagree, 3-neutral, 4-agree, 5-strongly agreeand two open-ended questions were used.All participants responded to the questionnaire voluntarily.Participants' information is kept confidential and anonymous. To ensure that the questionnaire was clear enough, it was translated into Vietnamese and piloted to 15 students. The major purpose of the pilot was to determine the feasibility of the main study and the advisable use of the instrument. The reliability of piloting questionnaire was 0.825 , which mean that the questionnaire is reliable for collecting official data.

\subsection{The participants}

Altogether 27 students were involved in the investigation. They come from Business Administration Department at a university in Mekong Delta. They were the third-year tourism students, were studying the fifth 
semester and their ages range from 20 to 26. Students have to complete three Basic English semesters before entering the specialized English semester. Their English knowledge is pre-intermediate level.

\section{Findings}

This section presents the findings from the research questions related to students' perceptions about using a website for vocabulary learning at a university in Vietnam. The findings show that most of the participating students had positive attitudes toward using a website to learn vocabulary, as illustrated in the following sections.

Table 1: The mean score of students' perceptions about the use of website in learning vocabulary

\begin{tabular}{llllll}
\hline & $\mathrm{N}$ & Minimum & Maximum & Mean & Std. Deviation \\
\hline MeanP & 27 & 3.85 & 5.0 & 4.4160 & .45 \\
\hline
\end{tabular}

A Descriptive Statistic Test was run to examine the total mean score of students' perceptions about using the website in learning vocabulary. Table 1 shows that the overall mean score of the use of the website in learning vocabulary is at a high level $(M=4.41, S D=.45)$. A One-Sample T-Test was conducted on students' perceptions about using the website in learning vocabulary to investigate whether the mean was significantly different from 3.5, medium level of students' perceptions about the use of vocabulary learning websites. There was significantly different from $3.5(t=10.693, d f=26, p=.00)$. It means that the mean score of students' perceptions about the use of the website in learning vocabulary was higher than the medium level. It can be inferred that students perceived the importance of using websites in learning vocabulary in the ESP classroom.

The findings from the questionnaire are illustrated in Table 2 below. Twenty-seven participating students responded to it. All the participants who answered the questionnaire used the website to learn specialized English vocabulary. The five-point scale responses were interpreted as "strongly agree and agree" responses, meaning students positively evaluated the statements suggested in the items questionnaire. Conversely, the "strongly disagree and disagree" responses mean that students negatively perceived the items questionnaire statements. The responses rest were thus neutral.

Table 2: Students' perceptions about the use of the EFL vocabulary website

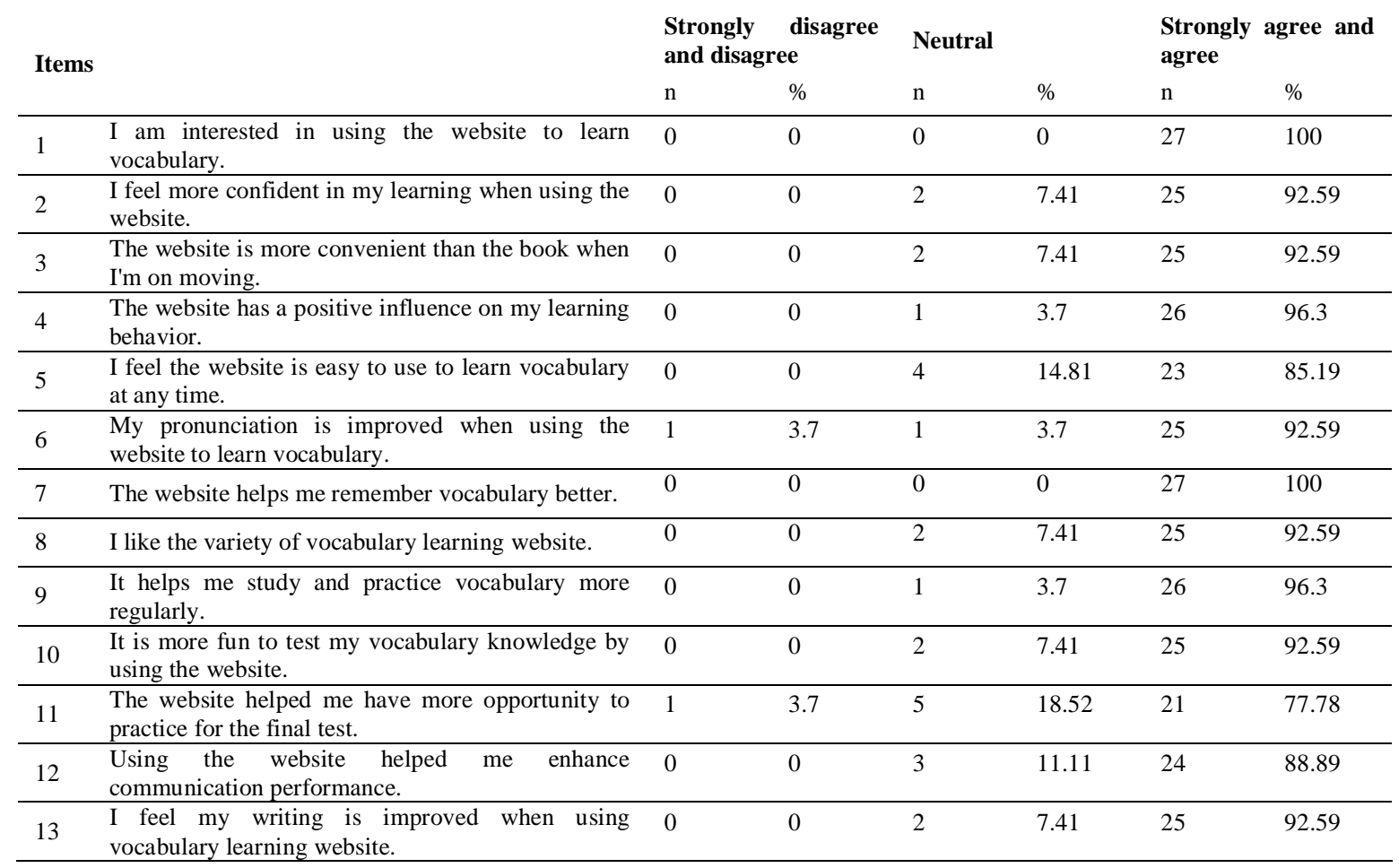


As can be seen from Table 2, all the participants agreed with Item 1, Item 7 that they were interested in using the website to learn vocabulary, and the website helped them remember vocabulary better. In responses to Item 3 , surveyed students appreciated the convenience of websites that they could access when moving, with the agreement $92.59 \%$ of respondents. $96.3 \%$ of the participant agreed that the website positively influenced their learning behavior (Item 4). $85.19 \%$ of the participant (Item 5) stated that the website was easy to use to learn vocabulary at any time. In terms of improving the students' pronunciation (Item 6), 92.59\% of the participants proved that the website helped students improve their pronunciation when using the website to learn vocabulary. In response to Item 8,9,10 which were about the various and enjoyable of the website, most of the participants agreed that participants had a variety of vocabulary learning website $(n=26)$. Participants also revealed that they could practice vocabulary more regularly with the website. $92.59 \%$ of the participants identified more fun and comfortable when they had vocabulary knowledge test through using website. $77.78 \%$ of the students agreed that the website helped students have more opportunities to practice for the final test (Item 11). Item 12, 13 regarding enhancing communication performance and students' writing, $88.89 \%$ of the students confirmed that they could enlarge their communication performance after using the website.92.58\% of the participant approved that their writing improved when using vocabulary learning websites.

From open-ended questions in the questionnaire, the participants expressed most things they like about website were convenient, easy to use, and practice. The following extract illustrated their view.

Website is convenient for studying. I can study by laptop or phone.(Student 3, questionnaire extract)

The website is very flexible for learners who want to learn a lot of vocabulary as well as practice. (Student 7 , questionnaire extract)

The website is interesting and easy to use. It is free to use this site. (Student 14, questionnaire extract)

I think the website is easy to log in, use, and make it easier to remember vocabulary. (Student 22, questionnaire extract)

I love learning to write new words with the website, it helps me learn faster. (Student 25, questionnaire extract)

In order to find what they like least about using website to learning ESP vocabulary, students shared that operating system of devices, Internet connection and were the things they did not like much. The following extracts illustrate their views.

I don't have a laptop, I use an iPhone. Sometimes it crashes with iOS operating system I have to log in again. (Student 8, questionnaire extract)

\section{Discussion}

The findings of the current study revealed that students had perceived positively when using website to learn vocabulary in ESP classroom. It is considered that website is a useful tool in blending learning when teaching vocabulary for students who are studying ESP vocabularies. The study is in line with several studies from the literature (Hajebiet el., 2018; Hoang, 2018; Klimova and Polakova, 2020; Köse et al., 2016). These authors confirmed that it increased students' interest and concentration in learning English vocabulary. The results of the findings showed that students less stressful when doing exercises on website. It is in line with the findings of Mufliharsi and Candra (2017). They confirmed that they can remember more words and increase their vocabulary naturally. This finding does not fit well with the study of Hoang (2018), participating students shared that website helps them study and practice vocabulary more regularly because they could use the website at anytime and anywhere. However, in Hoang's (2018) study, students did not use Internet effectively in improving their learning ability and their motivation.

\section{Conclusion}

The findings of the current study help draw consideration that using a website like easyword.incontributes a significant impact on fostering students' vocabulary in the ESP context, particularly in a university in Mekong 
Delta. Because of the potential effects of using easyword.in website, students have positive perceptions towards the website in learning vocabulary. There are some implications for teachers and students in teaching vocabulary. First, teachers should use activities of easyword.in website as supplemental practice for the students. Furthermore, the findings from the study may offer some experiences in designing vocabulary activities to stimulate students' minds to remember words better and longer.

\section{About the authors}

Ly Minh Trinh is a lecturer in English at Mekong University, Vietnam. Her research interests include teaching methodologies, listening skills, and ESP.

Son Hoang Le is a lecturer in University of Economics Ho Chi Minh City, Vietnam. His research interests include education, data mining and computer technology application.

\section{References}

[1] Alqahtani, M. (2015).The importance of vocabulary in language learning and how to be taught.International journal of teaching and education, 3(3), 21-34.

[2] Altiner, C. (2011). Integrating a computer-based flashcard program into academic vocabulary learning.Doctoral dissertation, Iowa State University, the USA. Retrieved March 10, 2014 from http://lib.dr.iastate.edu/cgi/viewcontent.cgi?article=1122\&context=etd

[3] August, D., Carlo, M., Dressler, C., \& Snow, C. (2005).The critical role of vocabulary development for English language learners.Learning Disabilities Research \& Practice, 20(1), 50-57.

[4] Dang, X. T. (2011). Factors influencing teachers' use of ICT in language teaching: a case study of Hanoi University, Vietnam. The $4^{\text {th }}$ edition of the ICT for Language Learning Conference. Retrieved April 27, 2014 from http://www.conference.pixel-online.net

[5] Dawson, K., Cavanaugh, C., \&Ritzhaupt, A. (2008). Florida's EETT Leveraging Laptops Initiative and its impact on teaching practices. Journal of Research on Technology in Education, 41(2), 143-159. https://doi.org/10.1080/15391523.2008.10782526

[6] Day, R., \&Bamford, J. (1998).Extensive Reading in the Second Language Classroom. Cambridge: Cambridge

[7] Ellis, N. C. (1994). Vocabulary acquisition: The implicit ins and outs of explicit cognitive mediation. Implicit and explicit learning of languages, 211-282.

[8] Godwin-Jones, R. (2011). Emerging technologies autonomous learning and technology.Language Learning, 15(3), 4-11

[9] Godwin-Jones, R. (2011). Mobile apps for language learning. Language learning \& technology, 15(2), 2-11.

[10] Graddol, D. (2004). The future of language.Science, 303(5662), 1329-1331.

[11] Gu, Y. (2003b). Fine brush and freehand: The vocabulary learning art of two successful Chinese EFL learners. TESOL Quarterly, 37, $73-104$.

[12] Hajebi, M., Taheri, S., Fahandezh, F., \&Salari, H. (2018).The role of Web-based language teaching on vocabulary retention of adult pre-intermediate EFL learners.Journal of Language Teaching and Research, 9(2), 372-378.

[13] Hoang, B.T. (2018). Using the Internet to Promote Business Learners' Autonomy in Vietnam.International Journal of Education and Literacy Studies, 6(3), 1-8.

[14] Hornby, A.S. (2006).Oxford Advanced Learner's Dictionary. Oxford: Oxford University Press.

[15] Ilyosovna, N. A. (2020). The Importance of English Language.International Journal on Orange Technologies, 2(1), 22-24.

[16] Khany, R., \&Khosravian, F. (2013).The application of Wikipedia for enhancing Iranian EFL students' reading proficiency.Proceeding of the global summit on education, 135-142.

[17] Klimova, B., \&Polakova, P. (2020).Students' perceptions of an EFL vocabulary learning mobile application.Education Sciences, $10(2), 37$.

[18] Kopinska, M. (2013). New technologies in foreign language classroom: the role of attitudes. The $6^{\text {th }}$ edition of the ICT for Language $\begin{array}{llllll}\text { Learning } & \text { Conference. } & \text { Retrieved } & \text { April } & 2014 & \text { from }\end{array}$ http://www.conference.pixel-online.net

[19] Köse, T., \& Mede, E. (2016). Perceptions of EFL learners about using an online tool for vocabulary learning in EFL classrooms: A pilot project in Turkey. Procedia-Social and Behavioral Sciences, 232, 362-372. 
DOI: $\underline{10.51386 / 25815946 / \mathrm{ijsms}-\mathrm{v} 4 \mathrm{i} 6 \mathrm{p} 110}$

Volume: 4 Issue: 6

November to December 2021

https://www.ijsmsjournal.org

[20] Kuo, L. L. (2009). The effects of YouTube listening/viewing activities on Taiwanese EFL learners 'listening comprehension (PhD thesis). Retrieved from http://www.proquest.com

[21] Liu, J. (2009). A survey of EFL learners' attitudes toward information and communication technologies.English Language Teaching, 2(4), 101-106.

[22] Marion, T. (2008).The effect of gestures on second language memorization by young children.Gesture, John Benjamins Publishing, $8(2), 219-235$.

[23] Mufliharsi, R., \&Candra, E. N. (2017).Improving students'ofnon-english department perspective in learning vocabulary through website.Getsempena English Education Journal, 4(2), 78-83.

[24] Nash, H., \&Snowling, M. (2006).Teaching new words to children with poor existing vocabulary knowledge: A controlled evaluation of the definition and context methods. International Journal of Language \& Communication Disorders, 41 (3), 335-354.

[25] Nation, I. S. P. (2001).Learning vocabulary in another language. Cambridge: Cambridge University Press.

[26] Nunan, David. (1991). Language Teaching Methodology. A Textbook for Teachers. London: Prentice Hall.

[27] Nurteteng, N., \&Nopitasari, D. (2019). The Use of Crossword Puzzle towards the Students Vocabulary. INTERACTION: JurnalPendidikanBahasa, 6(1), 9-17. https://doi.org/10.36232/jurnalpendidikanbahasa.v6i1.284

[28] Parvin, R. H., \& Salam, S. F. (2015).The effectiveness of using technology in English language classrooms in government primary schools in Bangladesh.FIRE: Forum for International Research in Education, 2(1), 47- 59. http://preserve.lehigh.edu/fire/vol2/iss1/5

[29] Patel, C. (2013). Use of multimedia technology in teaching and learning communication skill: An analysis. International Journal of Advancements in Research \& Technology, 2(7), 116-123

[30] Pino, D. (2008). Web-based English as L2 instruction and learning: Strength and Weakness. Retrieved from http://findarticles.com/p/articles/mi_hb5835/is_200803/ai_n32281702/

[31] PourhosseinGilakjani, A., \&Sabouri, N. B. (2014).Role of Iranian EFL teachers about using Pronunciation Power software in the instruction of English pronunciation.English Language Teaching, 7(1), 139-148. doi: http://dx.doi.org/10.5539/elt.v7n1p139

[32] Richards, C J (2001).Curriculum development in language teaching, CUP.UK: Cambridge university press.

[33] Rivers, Wilga M. (1989). Communicating Naturally in a Second Language Theory and Practice in Language Teaching. Cambridge: Cambridge University Press.

[34] Schmitt, N. (2000). Vocabulary in language teaching.Cambridge, UK: Cambridge University Press

[35] Schmitt, N., Ng, J. W. C., \&Garras, J. (2011). The word associates format: Validation evidence. Language Testing, 28(1), $105-126$.

[36] Teeler, D. \& Gray, P. (2000).How to use the Internet in ELT. Pearson Education Limited.

[37] Tozcu, A., \&Coady, J. (2004). Successful learning of frequent vocabulary through CALL also benefits reading comprehension and speed. Computer assisted language learning, 17(5), 473-495.

[38] Ur, P. (2009).A Course in Language Teaching.Cambridge University Press.

[39] Vu, D. V., \& Michel, M. (2021).An exploratory study on the aspects of vocabulary knowledge addressed in EAP textbooks.Dutch Journal of Applied Linguistics, 10.https://doi.org/10.51751/duja19345

[40] Wilkin, D. (1972). Linguistics in language teaching.Edward Arnold: London. 